\title{
COST OPTIMIZATION OF ELECTRICAL ENERGY USED FOR WATER EXTRACTION
}

\author{
Velimir Golub \\ Vodovod-Osijek d.o.o., Osijek, M.EE. \\ Darko Dubovicki \\ Vodovod-Osijek d.o.o., Osijek, B.EE. \\ Bojan Lazar \\ Vodovod-Osijek d.o.o., Osijek, B.EE. \\ Dubravko Pichler \\ Vodovod-Osijek d.o.o., Osijek, M. E. Food Engineering \\ Corresponding author:dubravko.pichler@vodovod.com
}

\begin{abstract}
The goal nowadays is to save electrical energy required for water extraction, conditioning and distribution to consumers since it represents the biggest cost in terms of water supply. The topicality of the issue prompted Vodovod-Osijek d.o.o. to analyze the potential electrical energy savings in terms of water extraction and distribution to the city of Osijek. This paper describes water-treatment-related processes along with a comparison of electrical energy consumption with and without a frequency converter.
\end{abstract}

Keywords: cost optimization, frequency converter, electrical energy, water

\section{SMANJENJE TROŠKOVA ELEKTRIČNE ENERGIJE U SVRHU CRPLJENJA VODE}

Sažetak: U današnje vrijeme cilj je ostvariti uštedu električne energije potrebne za crpljenje vode, kondicioniranje vode i njezinu distribuciju potrošačima, što je najveći trošak u postupku opskrbe vodom. Aktualnost ovog problema potaknula je Vodovod-Osijek na analizu mogućih ušteda električne energije u svrhu crpljenja i distribucije vode za grad Osijek. U ovome radu opisani su procesi vezani za preradu vode, uz usporedbu utroška električne energije $\mathrm{s}$ frekvencijskim pretvaračem i bez njega.

Ključne riječi: ušteda, frekvencijski pretvarač, električna energija, voda 


\section{INTRODUCTION}

The goal nowadays is to save electrical energy required for water extraction, conditioning and distribution to consumers since it represents the biggest cost in terms of water supply. Many countries are faced with this issue and are trying to reduce electrical energy consumption of the water supply system. The issue is becoming bigger each year due to rising oil prices, which in turn increase the water extraction cost, but also due to higher water consumption. To exemplify, 18 years ago, Portugal did not have this problem at all, whereas today it explores ways to apply renewable energy sources in water extraction [1]. Aside from applying renewable energy sources (primarily solar energy and wind power), other possibilities of reducing electrical energy consumption are also being analyzed and as such they have to be cost-effective, environmentally friendly and thus innovative. One of such solutions is the option of installing water turbines into the water supply system itself, which would be used to exploit the energy of water in the water supply network, which would in turn be subsequently transformed into electrical energy [2].

The issue of water supply system energy could be observed and analyzed from two standpoints: as an issue of minimizing energy consumption and as an issue of maximizing the usability of energy by analyzing the system in its entirety (pipe diameter, losses, pump operation). The optimal water supply system configuration should meet both criteria [3].

According to Feldman [4], the energy efficiency of the water supply system can be increased by improving the pumping station and distribution network designs, by increasing pump efficiency by way of frequency converters and by decreasing network losses $[5,6]$.

According to Watergy (2009), two to three percent of world energy is used for water extraction and conditioning for the purpose of public water supply. By applying different models and operational strategies, it could be decreased by around $25 \%$ [7]. The monitoring of four water supply systems in the USA has shown that measuring of efficiency of every pump in the system and bringing it to the point of maximum efficiency improves the average efficiency of the entire system (by 6-9\%) [8].

The topicality of the issue prompted Vodovod-Osijek d.o.o. to analyze the potential electrical energy savings in terms of water extraction and distribution to the city of Osijek. This paper describes water-treatment-related processes along with a comparison of electrical energy consumption with and without a frequency converter.

\section{ABOUT VODOVOD-OSIJEK d.o.o.}

Vodovod-Osijek d.o.o. was established in 1884 with the first pumping station for the distribution of water to the city of Osijek being installed on the Solarski Square. In 1960, a new water treatment plant was built where the today's Vodovod-Osijek d.o.o. is situated and the intake structure "Pampas" (Figure 1.b) was built by the river Drava. During the 1970s, the quality of the Drava water decreased significantly, causing the need for a new water source. For this purpose, new water wells were drilled on the "Vinogradi" location (Figure 1.a). The intake source "Pampas" still serves as a stand-by well field. Vodovod-Osijek d.o.o. currently supplies potable water to the city of Osijek and the suburban settlements: Višnjevac, Josipovac, Briješće, Livana, Antunovac, Ivanovac, Ernestinovo, Laslovo, Divoš, Brijest, Tenja, Sarvaš, Bijelo Brdo, Čepin, Podravlje i Tvrđavica [9].

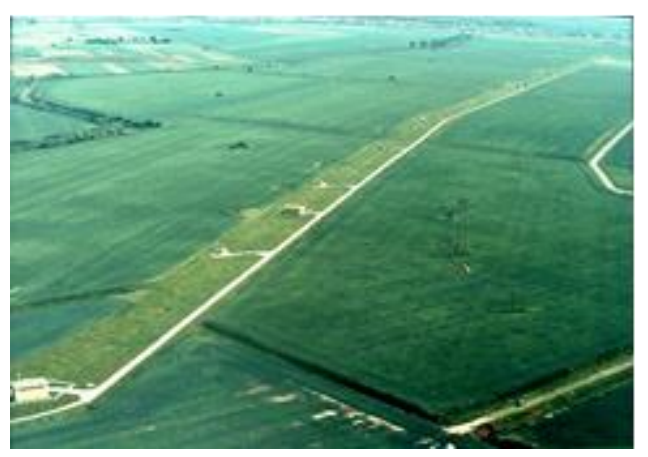

a)

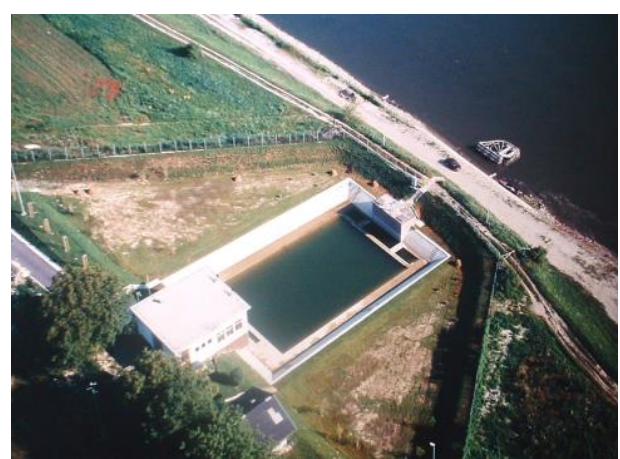

b)

Figure 1 a) Well field "Vinogradi" and b) Intake structure "Pampas" 


\subsection{Raw Water Treatment Process}

The water supply system of the city of Osijek is a complex system comprising

- the intake structure "Pampas" and well field "Vinogradi",

- the water treatment plant,

- the $10000 \mathrm{~m}^{3}$ reservoir,

- the water supply pumping station and

- the water supply network.

The well field "Vinogradi" lies $7 \mathrm{~km}$ from the water treatment plant, which is located between the Osijek beltway, the Slavonika highway and the settlement Čepin. The water is extracted from the aquifers that hold the wells. The well field from which raw water is extracted has 18 wells that are $400 \mathrm{~mm}$ in diameter and 120 to 180 meters deep. Inside a well, submersible pumps are placed $40 \mathrm{~m}$ below ground level. The pumps of a nominal flow of $50 \mathrm{l} / \mathrm{s}$ are run by a $42-\mathrm{kW}$ three-phase electric motor and operated by a frequency converter.

1. AERATION is carried out by injecting air into water to achieve the maximum amount of oxygen in water, i.e. around $8 \mathrm{mg}$ of $\mathrm{O}_{2}$ per $1 \mathrm{~L}$ of water.

2. PRE-OXIDATION is carried out by adding $1 \%$ potassium permanganate $\left(\mathrm{KMnO}_{4}\right)$ solution containing 0.3 $\mathrm{mg} \mathrm{Mn/L}$ of water.

3. COAGULATION is carried out by adding $40 \%$ ferric chloride $\left(\mathrm{FeCl}_{3}\right)$ solution containing 3 to $5 \mathrm{mg} \mathrm{Fe} / \mathrm{L}$ water.

4. FLOCCULATION is carried out by adding $0.05 \%$ polyelectrolyte solution.

5. SEDIMENTATION is carried out on two lines, with one line consisting of six sedimentation tanks and four precipitators and the other of two accelerators.

6. FILTRATION AND NITRIFICATION is carried out on Filters 1,2 and 3. The filter mediums used include silica sand and anthracite.

7. DISINFECTION is carried out using chlorine gas, after which the water is stored in four $10000-\mathrm{m}^{3}$ reservoirs.

8. SUPPLYING of water to the consumer takes place in the pumping station "Nebo pustara". The pumping station does not have a water tower: water is supplied to the city with the set pressure required by the water supply network by way of submersible pumps that are operated by frequency converters.

Figure 2 shows the diagram for the water treatment process.

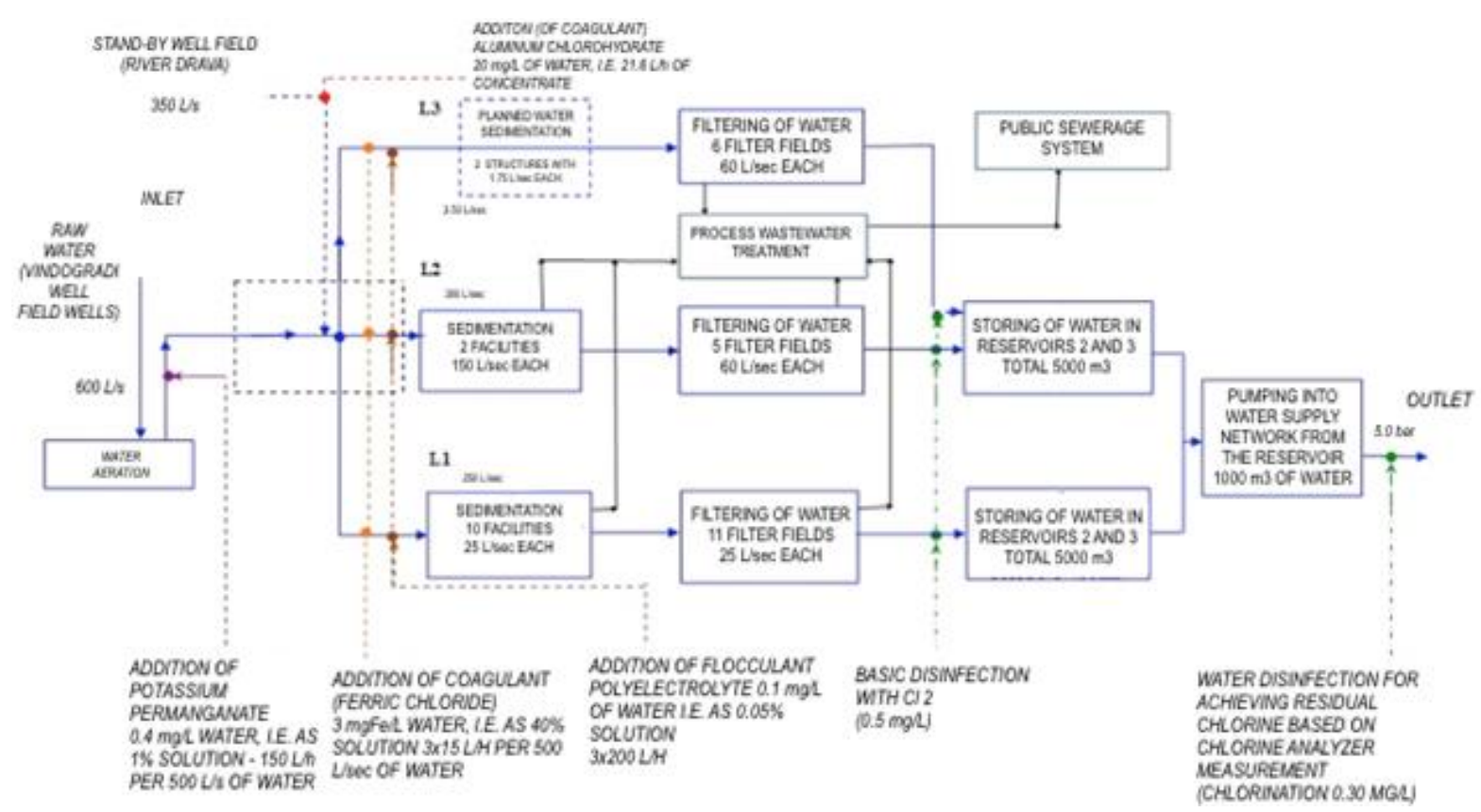

Figure 2 Water Treatment Process Diagram 


\section{THE ROLE OF FREQUENCY CONVERTERS IN THE WATER SUPPLY SYSTEM}

Frequency converters have multiple roles [10,11, 12]:

- The basic role is the starting and stopping of pumps according to the set parameters. The starting and stopping is important because of the water hammer occurring on the well casing and the backfilled silica sand around the well (Figure 4).

- $\quad$ Another important requirement is the maintaining of the set pressure during water extraction. The above requirement affects the stability of the well operation and the decrease in the total electrical power input during onpeak tariff periods.

- Preserving the age of the well: during continuous operation, the well is losing the amount of water that can be supplied. Aside from the above requirement, it is also necessary to maintain the water column level inside the well. Figure 3 shows the relationship between the level in the well and the flow over the years of operation.

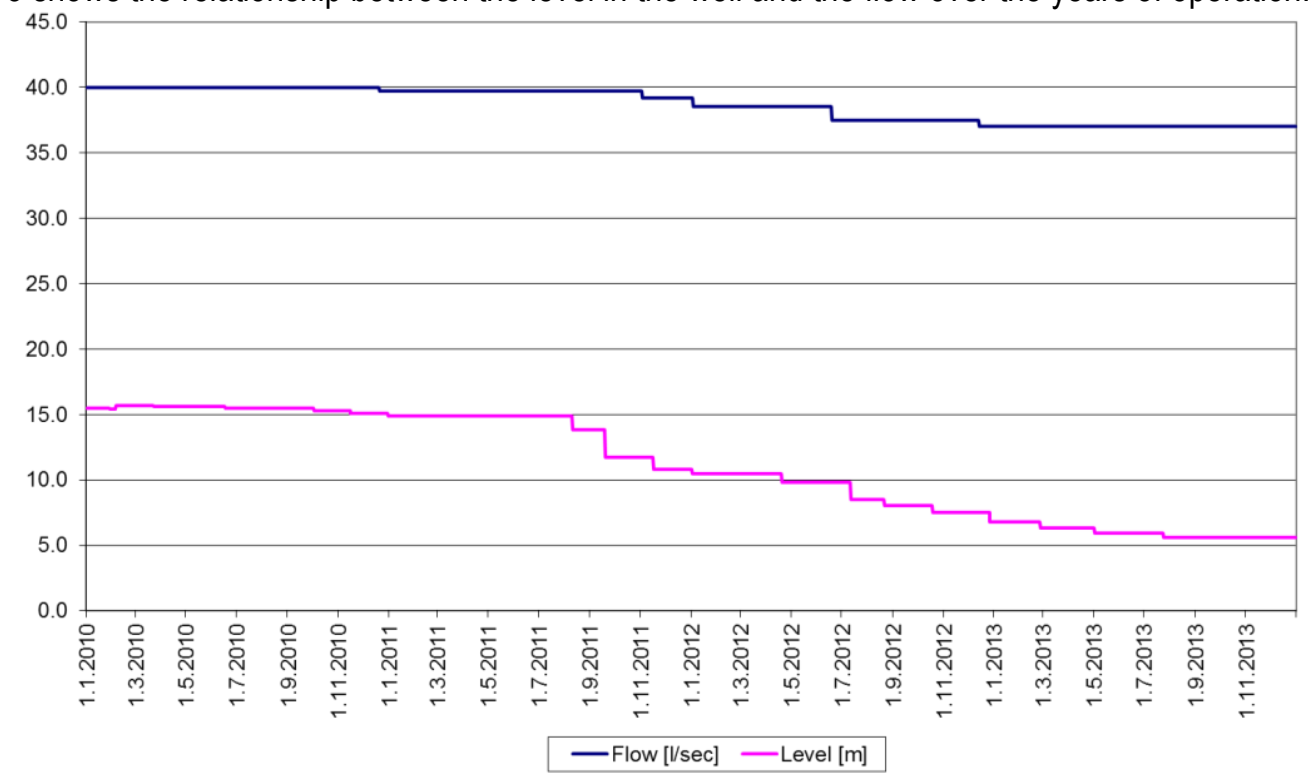

Figure 3 Level and flow of the well water over the course of four years

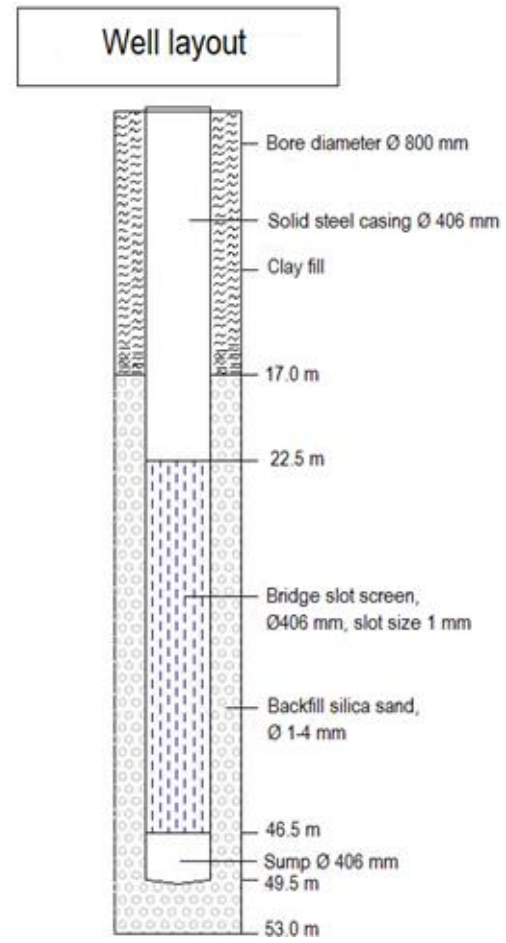

Figure 4 Well cross-section 


\section{ELECTRICAL ENERGY AND INPUT POWER SAVINGS ON WATER EXTRACTION PUMPS}

The role of the frequency converter correlates to the electrical energy savings and consumption as shown in Figure 5.

The red line shows the input power used for pump starting without frequency converter control in a Y- $\Delta$ connection. The blue line depicts the input power with the frequency converter. It is evident that the amount of water supplied with the use of the frequency converter allows for $25 \%$ savings in electrical energy and input power. In terms of the well field "Vinogradi", electrical energy savings under regular pump operation amount to $1 \mathrm{GWh}$ of electrical energy in one year.

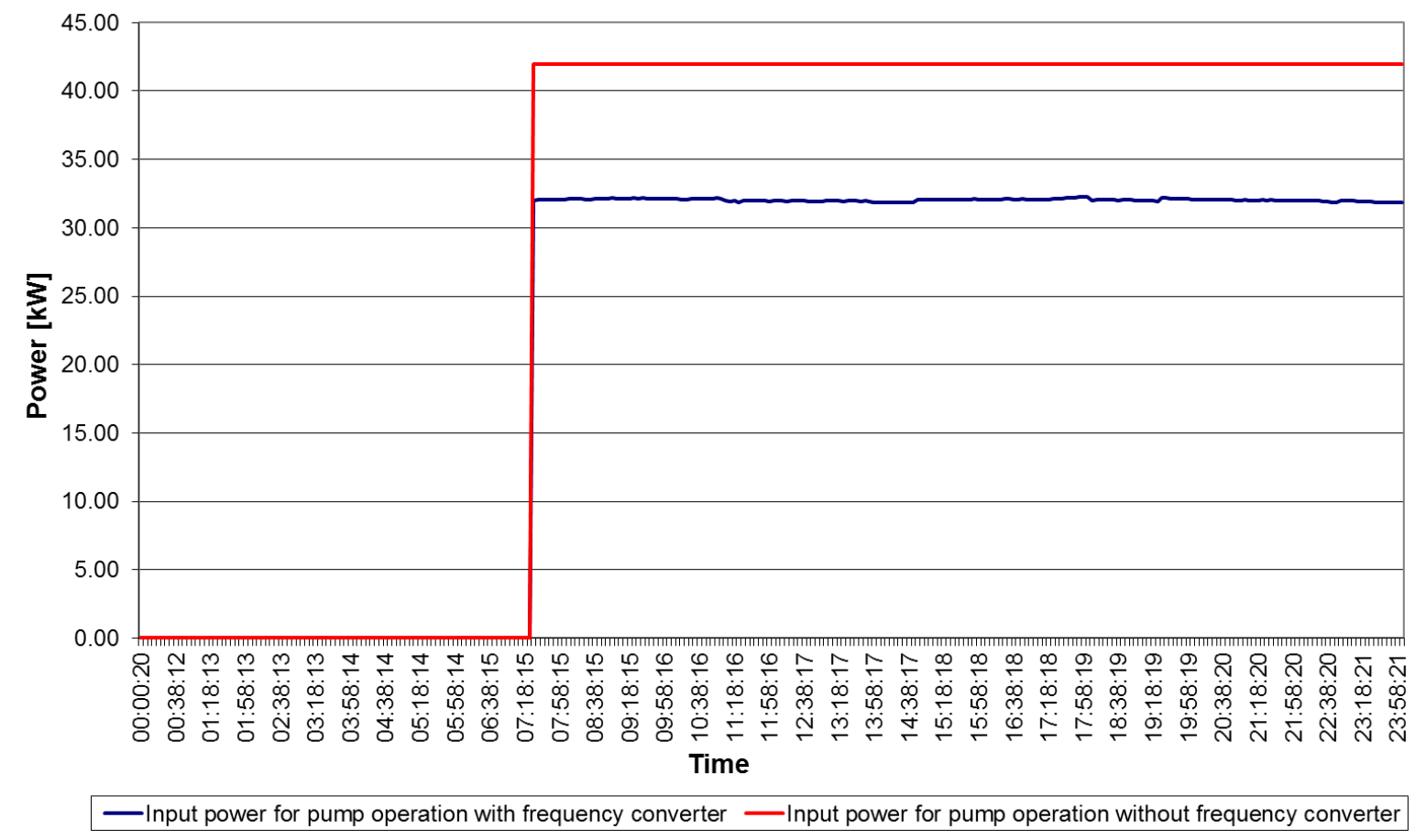

Figure 5 Input power for pump operation by way of frequency converter and $Y-\Delta$ connection

\subsection{Electrical Energy Savings by Selecting Pump Operation Mode}

Vodovod-Osijek d.o.o. has an algorithm for water procurement, treatment and supply to the water supply network. In short, during off-peak tariff times (nighttime tariff), a maximum number of water extraction pumps is put into operation. The basic reasoning behind it is that, during the said times, the input electrical power is not recorded and the price per kWh of electrical energy is lower.

The diagram in Figure 6 shows electrical energy consumption during on-peak (ON-PTT) and off-peak tariff times (OFF-PTT) of the well field "Vinogradi" and the water treatment plant "Nebo pustara". 


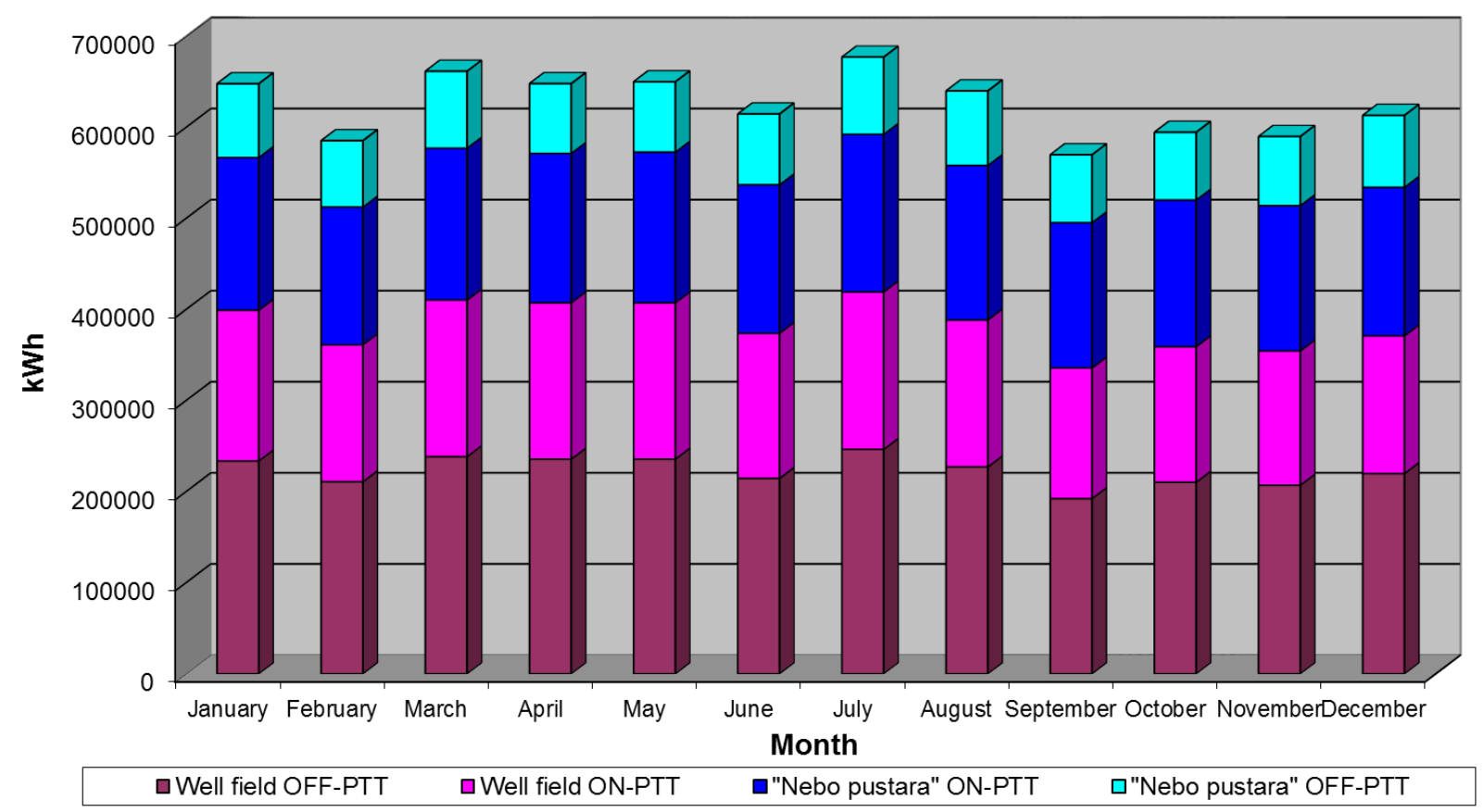

Figure 6 Electrical energy consumption during on-peak and off-peak tariff times

Water extraction, treatment and distribution to the city consumes $7.5 \mathrm{GWh}$, of which $4 \mathrm{GWh}$ are consumed during on-peak tariff times and $3.5 \mathrm{GWh}$ during off-peak tarrif times, with the average input power of $610 \mathrm{~kW}$ on the well field "Vinogradi" and $520 \mathrm{~kW}$ on the "Nebo pustara" facility location.

Splitting the Figure 6 diagram into the well field "Vinogradi" location and the water treatment plant location shows the following: the electrical energy consumption of the well field "Vinogradi" during on-peak and off-peak tariff times is shown in Figure 7, demonstrating the example of electrical energy savings. The consumption is increased during off-peak tariff times due to the reservoirs being filled to their maximum level during night.

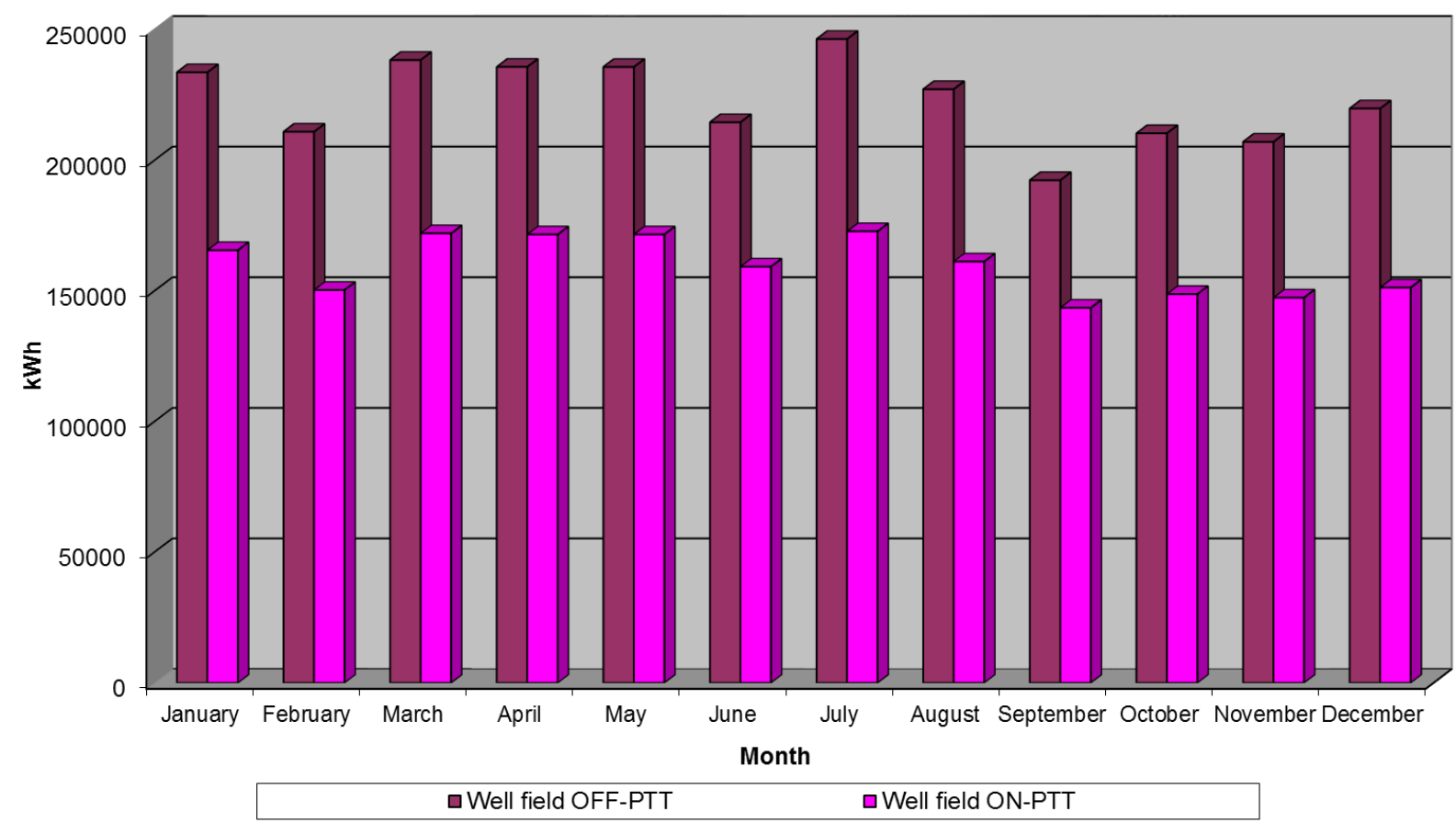

Figure 7 Electrical energy consumption of the well field "Vinogradi" during on-peak and off-peak tariff times 
The operation modes of the plant "Nebo pustara" and the well field "Vinogradi" are opposite. Water distribution pumps operate in day mode, which cannot be changed mainly due to the need for potable water that is significantly greater in day mode than in night mode. Figure 8 shows how on-peak and off-peak tariff times in this regard relate to one another.

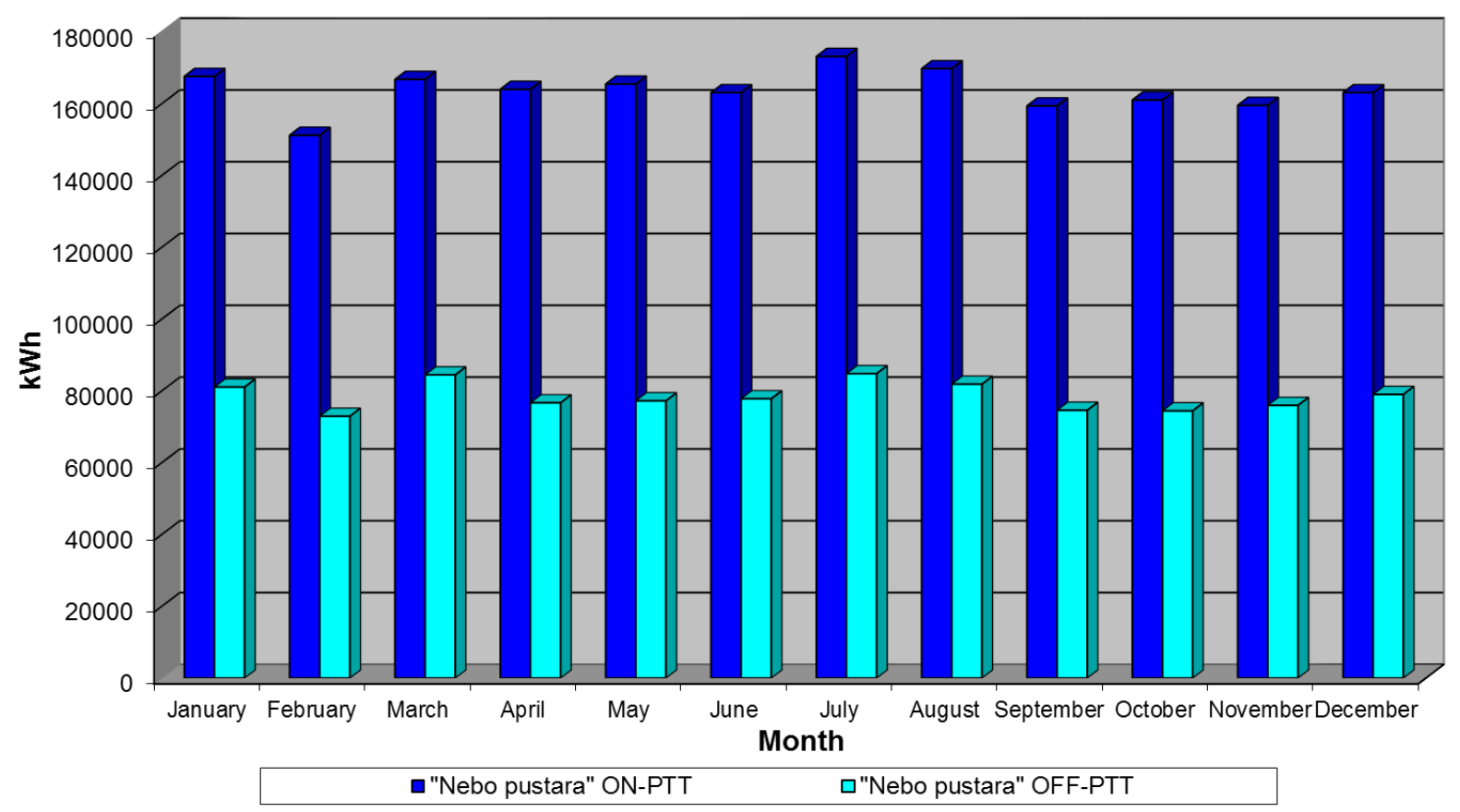

Figure 8 Electrical energy consumption of the plant "Nebo pustara" during on-peak and off-peak tariff times

\subsection{Filling and Emptying of the Water Reservoir}

The diagram in Figure 9 shows the water level in the reservoir that holds the water supply pumps. The filling and emptying of the reservoir relates closely to the previously described extraction and delivery processes. In night mode, the $10000-\mathrm{m}^{3}$ reservoir is filled to its maximum, which is reached in the morning. The pumps on the well field "Vinogradi" continue to supply water in saving mode and keep refilling the reservoir to a level of $5000 \mathrm{~m}^{3}$ and not below since it is the prescribed minimum for potable water supplies in case of undesired events.

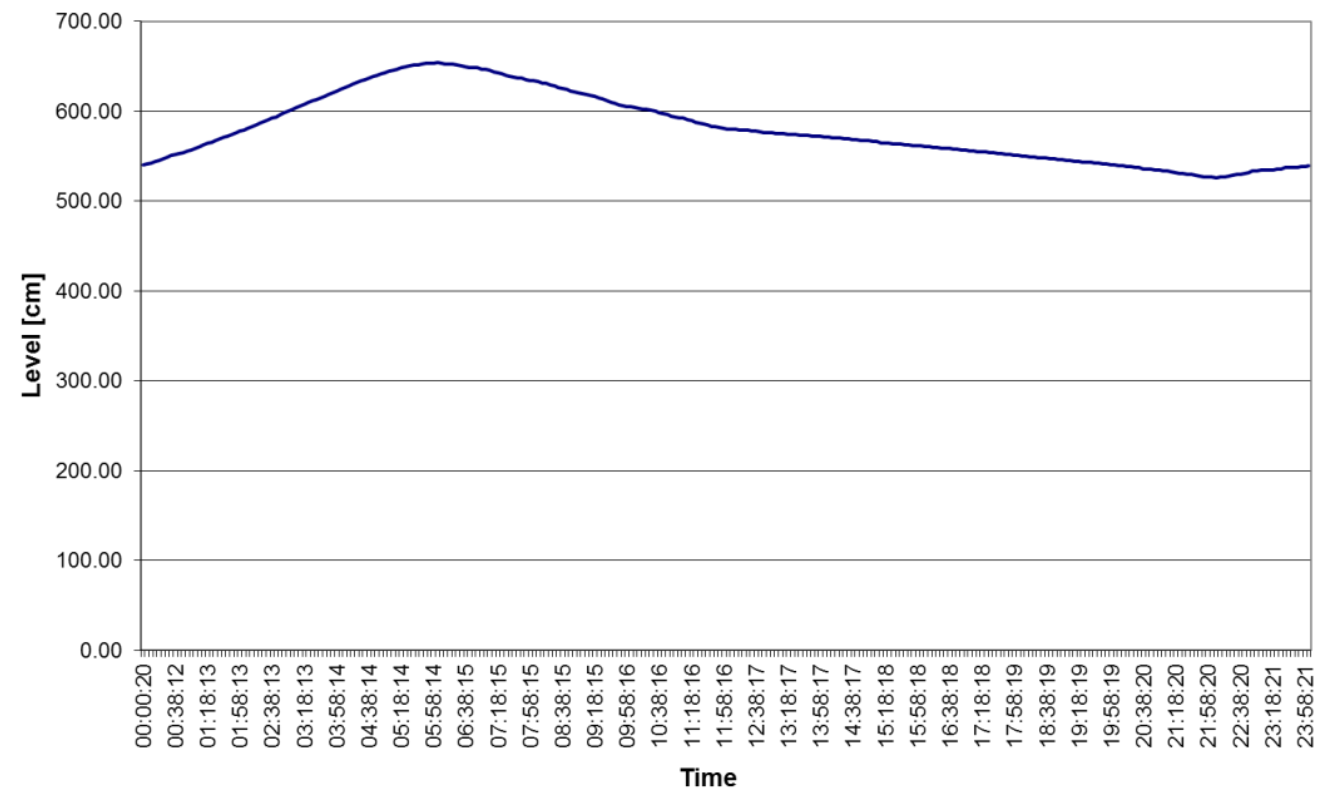

Figure 9 Water Reservoir Level 
Figure 10 shows the comparison of electrical energy consumption with and without frequency converters $(F C)$ as well as the respective savings. The dashed lines represent the pump motor nominal power that would be used in case of pump operation without a frequency converter. Purple columns represent the well field "Vinogradi" and the red ones the plant "Nebo pustara". The savings are evident in the difference between the dashed line and the values shown.

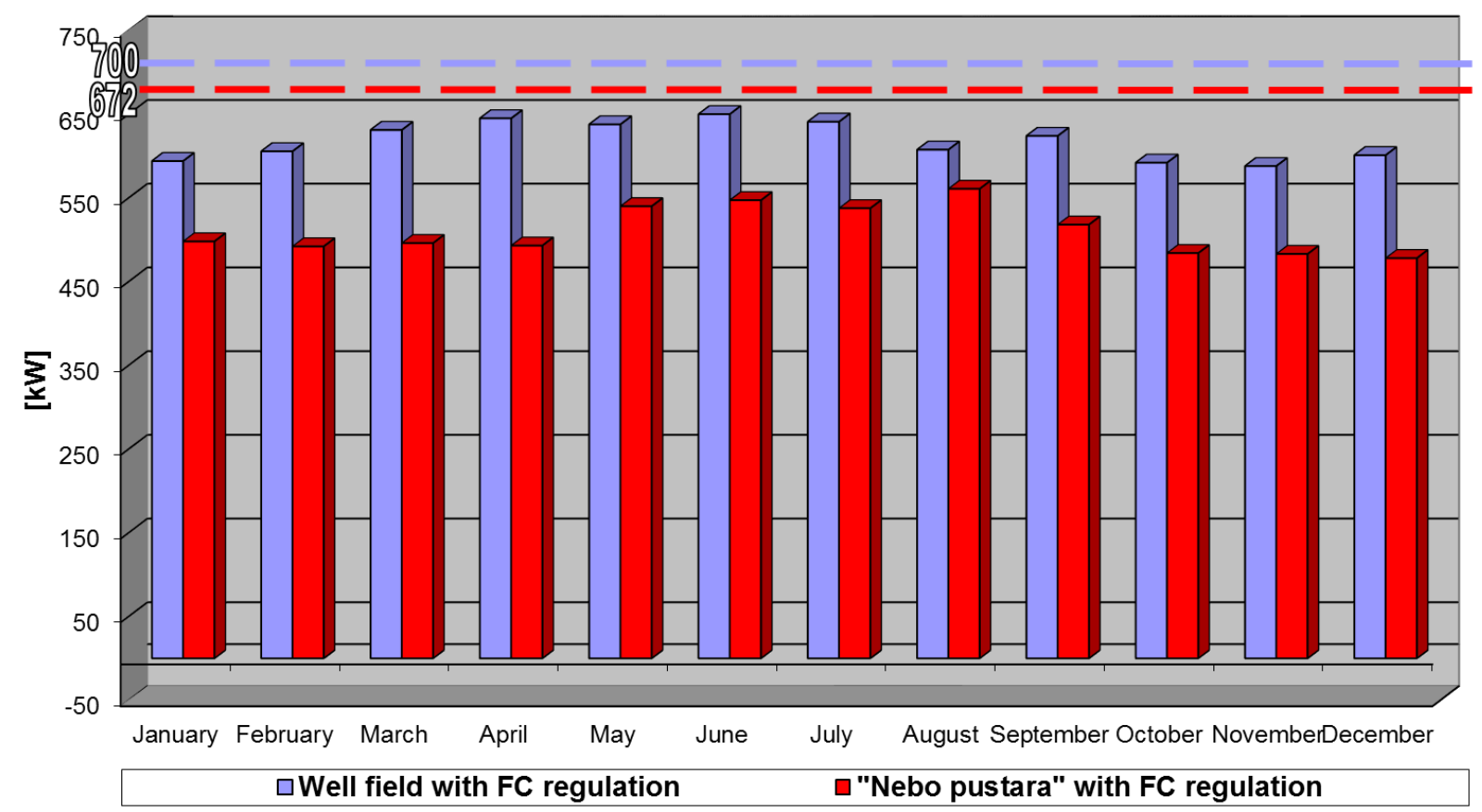

Figure 10 Input power

\section{CONCLUSION}

The use of frequency converters contributed significantly to electrical energy savings owing to the fact that the controlling of the rotation speed of the pump motor extends the engine lifetime. The selection of the appropriate parameters on the frequency converter determines the motor start time, thereby reducing the effect of the water hammer and the hit of electrical energy to the network. The flow regulation is not carried out by closing valves, owing to which pumps no longer operate with nominal power. As demonstrated by the diagrams, there are savings in more than one area: from extending the lifespan of wells and motors to electrical energy and input power. The human factor in terms of savings is indispensable: the very selection of the operating mode, with the electrical energy being less costly during night time, we knowingly affect electrical energy savings.

\section{References}

[1] Ramos, J.S.; Ramos, H.M., 2009: Sustainable application for renewable sources in water pumping systems: Optimized energy system configuration, Energy Policy, 37(2), pp. 633-643, doi:10.1016/i.enpol.2008.10.006

[2] Ramos, H.M.; Kenov, K.N.; Vieira, F., 2011: Environmentally friendly hybrid solutions to improve energy and hydraulic efficiency in water supply system, Energy for Sustainable Development, 15 (4), pp. 436-442, doi:10.1016/i.esd.2011.07.009

[3] Bolognesi, A.; Bragalli, C.; Lenzi, C.; Artina, S., 2014: Energy efficiency optimization in water distribution, Procedia Engineering, Vol.70, Proceedings of 12th International Conference on Computing and Control for Water Industry, CCWI2013), pp. 181-190, doi:10.1016/i.proeng.2014.02.021

[4] Feldman M., 2009: Aspects of Energy Efficiency in Water Supply, http://www.miyawater.com/user_files/Data_and_Research/miyas_experts_articles/08_Other\%20aspects $\% 20$ of $\% 20$ NRW/01 _Aspects\%20of\%20Energy\%20Efficiency\%20In\%20Water\%20Supply\%20Systems.pdf (visited January 10. 2015) 
[5] Coelho, B.; Andrade-Campos, A., 2014: Efficiency Achievement in Water Supply Systems - A Review, Renewable and Sustainable Energy Reviews, Vol. 30, pp. 59-84, doi:10.1016/i.rser.2013.09.010

[6] Vilanova, M.R.N.; Balestieri, J.A.P., 2014: Energy and hydraulic efficiency in conventional water supply system, Renewable and Sustainable Energy Reviews, Vol. 30, pp. 701-714, doi:10.1016/j.rser.2013.11.024

[7] Ramos, H.M.; Costa, L.H.M.; Gonçalves , F.V., 2012: Energy Efficiency in Water Supply Systems: GA for Pump Schedule Optimization and ANN for Hybrid Energy Prediction, http://dx.doi.org./10.5772/50458

[8] Reynolds, L.K.; Bunn, S., 2010: Improving energy efficiency of pumping systems through real-time scheduling systems, In Boxal J., and Maksimović Č.(eds) Integrating Water Systems: Proceedings of the 1oth International Conference on Computing and Control in the Water Industry, Taylor and Francis Group, London, pp. 326-330

[9] Živaković Kerže, Z.: „Voda i grad - povijest vodoopskrbe grada Osijeka“

[10] Vuković, A., 1999: Proizvodnja vode u PJ Vodoopskrba, Vodovod - Osijek

[11] Borić, Z., 2009: Frekvencijski pretvarači

[12] Najvažnije o frekvencijskim pretvaračima, 2010, Graphis 